\title{
Pengembangan Aplikasi Pengenalan Tokoh Pahlawan dan Kebudayaan Melalui Patung di Pantai Losari Makassar Menggunakan Teknologi Machine Learning Kit Berbasis Android
}

\author{
Aswin Asrianto ${ }^{1}, \mathrm{Al} \mathrm{Imran}^{2}$, Hasrul Bakri ${ }^{3}$ \\ ${ }^{1,2,3}$ Universitas Negeri Makassar \\ laswinck. teamegmail.com \\ 2al.imraneunm.ac.id \\ ${ }^{3}$ hasrulbakri@unm.ac.id,
}

\begin{abstract}
Abstrak - Penelitian ini merupakan penelitian pengembangan perangkat lunak yang bertujuan untuk menghasilkan aplikasi pengenalan tokoh pahlawan dan kebudayaan melalui patung di pantai Losari Makassar berbasis android dengan memanfaatkan teknologi machine learning kit serta untuk mengetahui hasil uji kelayakan terhadap aplikasi. Model pengembangan yang digunakan adalah prototipe dan menggunakan pengujian standar kualita ISO / IEC 25010 dengan menguji 4 aspek yaitu functionality, suitability, portability, efficiency, dan usability. Data penelitian diperoleh menggunakan wawancara, observasi dan angket. Data penelitian dianalisis dengan menggunakan teknik analisis statistik deskriptif. Hasil dari penelitian ini adalah 1) Aplikasi pengenalanTokoh pahlawan dan kebudayaan melalui patung di pantai Losari menggunakan android dengan penyajian informasi melalui scan replika patung hingga informasi ditampilkan dari objek yang terdeteksi serta informasi detail dapat dilihat langsung melalui menu galery. 2) Hasil pengujian aplikasi menggunakan ISO / IEC 25010 pada aspek functionality, suitability, portability, efficiency, dan usability aplikasi berkualitas baik.
\end{abstract}

Kata Kunci - Mechine Learning, ISO / IEC 25010, Pahlawan dan Kebudayaan

\section{PEndahuluan}

Kota Makassar merupakan Ibukota Provinsi Sulawesi Selatan yang disejajarkan dengan kota-kota besar Indonesia lainnya yang memiliki potensi besar untuk pengembangan pariwisata karena Kota Makassar merupakan pusat pengembangan, perjalanan, dan pintu gerbang di Kawasan Timur Indonesia [1]. Potensi Kota Makassar untuk pengembangan wisata dapat dilihat dari beberapa objek wisata yang sudah ada dan terus dikembangkan, seperti Fort Rotterdam, Makam Sultan Hasanuddin, Makam Raja-raja Tallo, Monumen Mandala, Pusat Rekreasi Pantai Akkarena, Balla Lompoa, dan wisata Pantai Losari. Dari beberapa objek wisata yang ada, Pantai Losari menjadi objek wisata yang terus dikembangkan dan menjadi meeting point oleh masyarakat maupun pengunjung dari luar daerah Kota Makassar, dengan aktivitas dan kehidupan di sepanjang pantai berlangsung selama 24 jam [2]. Anjungan Pantai yang dibangun tediri atas 4 bagian untuk mewakili suku yang ada di sulawesi selatan, yaitu Anjungan Makassar, Anjungan Bugis, Anjungan Mandar dan Anjungan Toraja. Setiap anjungan memiliki ciri khas berupa replika patung yang melambangkan adat dan kebudayaan Sulawesi Selatan, serta beberapa replika patung tokoh pahlawan Sulawesi Selatan [3].

Menurut Wali Kota Makassar, Danny Pomanto Kehadiran replika patung yang menghiasi Pantai Losari tidak lepas dari peran pemerintah untuk memperkenalkan adat dan kebudayaan yang ada di Sulawesi Selatan serta menjadi sarana untuk lebih mengenal tokoh pahlawan Sulawesi Selatan [4]. Namun demikian, kehadiran replika patung di Pantai Losari belum sepenuhnya memperkenalkan adat dan kebudayaan serta tokoh pahlawan Sulawesi Selatan kepada pengunjung karena minimnya informasi yang jelas mengenai patung tersebut. Berdasarkan fakta di lapangan, pada replika patung yang ada hanya menampilkan keterangan nama saja dan tidak menampilkan informasi yang lebih mengenai tokoh pahlawan dan kebudayaan yang menjadi simbol dari replika patung itu sendiri sehingga pengunjung kesulitan untuk mendapatkan informasi yang jelas terkait replika patung di Pantai Losari. Selain itu beberapa pengunjung belum sepenuhnya mengetahui tujuan diperadakannya replika patung tersebut sehingga hanya digunakan sebagai objek foto saja.

Berdasarkan permasalahan tersebut, dapat disimpulkan bahwa dibutuhkan adanya sumber informasi yang lengkap terkait keberadaan replika patung di Pantai Losari. Informasi dapat diketahui dengan memanfaatkan teknologi smartphone sehingga memudahkan pengunjung untuk mendapatkan informasi tentang patung-patung yang terdapat pada Anjungan Pantai Losari. Dukungan teknologi tentu saja sangat mempengaruhi tingkat efektivitas dalam menyelesaikan permasalahan ini. Fakta menunjukkan bahwa saat ini sebagian besar perangkat telepon genggam yang ada di dunia tidak terkecuali di Indonesia berupa smartphone. Smartphone dengan sistem operasi android menjadi smartphone yang paling banyak digunakan. Hal tersebut menjadi salah satu pendukung pengembangan produk penelitian berupa aplikasi berbasis android, sehingga mampu menjaring pengguna dalam jumlah besar. Replika patung di Pantai Losari dapat diketahui melalui sebuah teknologi berbasis machine learning (pembelajaran mesin) untuk memindai dan mengklasifikasikan objek patung tersebut untuk menampilkan informasi sehingga memudahkan para pengunjung untuk mendapatkan informasi tentang patung-patung yang terdapat pada Anjungan Pantai Losari.

Berdasarkan latar belakang yang telah diuraikan, maka penelitian ini bertujuan untuk menghasilkan aplikasi pengenalan tokoh pahlawan dan kebudayaan di pantai losari makassar dengan teknologi machine learning kit serta mengetahui hasil uji kelayakan aplikasi menggunakan ISO/IEC 25010.

\section{METODE PENELITIAN}

Pembahasan pada bagian II menjelaskan jenis penelitian, waktu dan tempat penelitian, model pengembangan, prosedur penelitian, teknik pengumpulan data, instrumen penelitian, uji validitas instrumen, dan teknik analisis data.

A. Jenis Penelitian

Jenis penelitian ini adalah penelitian pengembangan perangkat lunak yang bertujuan untuk menghasilkan sebuah produk aplikasi. Produk yang dihasilkan adalah "Losari Statue" yang berupa 
aplikasi pengenalan tokoh pahlawan dan kebudayaan dari replika patung Pantai Losari dengan memanfaatkan teknologi machine learning kit.

B. Waktu dan Tempat Penelitian

Penelitian ini dilaksanakan di Laboratorium Komputer Pendidikan Teknik Informatika dan Komputer Universitas Negeri Makassar. Penelitian dilaksanakan pada bulan September 2020November 2020.

\section{Model Pengembangan}

Dalam pembuatan dan pengembangan aplikasi diperlukan suatu model pengembangan sistem yang akan menentukan proses penyelesaian rekayasa perangkat lunak, adapun pendekatan sistem yang digunakan adalah metode prototipe. Prototipe adalah proses itertative (pengulangan) yang melibatkan hubungan kerja yang dekat antara perancang dengan pengguna [5]. Metode prototipe sangat efektif untuk mengembangkan perangkat lunak secara cepat dengan melibatkan pengguna dalam analisa dan desain. Kuncinya adalah mendapatkan kebutuhan dan aturan yang jelas yang disetujui pengguna dan pembuat perangkat lunak.

\section{Prosedur Penelitian}

Berdasarkan model pengembangan yang dipilih, tahapantahapan dalam penelitian ini, yaitu:

1. Analisis dan pengumpulan data

Tahapan awal yang dilakukan adalah analisis dan pengumpulan data, yaitu menganalisis permasalahan yang dihadapi pemerintah kota Makassar serta masyarakat terkait keberadaan replika patung di pantai losari sebagai sarana edukasi untuk lebih mengenal tokoh pahlawan dan kebudayaan yang ada di Sulawesi Selatan dan mengumpulkan data-data yang diperlukan. Analisis permasalahan dilakukan dengan melakukan observasi serta wawancara di Pantai Losari

2. Membangun Prototipe

Membangun prototipe dengan membuat rancangan sementara berupa gambaran proses yang dapat dilakukan oleh perangkat lunak yang akan dikembangkan dengan tampilan serta direncanakan sesuai dengan analisis kebutuhan. Membangun prototipe ini dilakukan dengan membuat use case diagram, sequence diagram, activity diagram, flowchart, dan pengembangan user interface.

3. Evaluasi Prototipe

Evaluasi ini dilakukan oleh penulis dengan memperlihatkan prototipe yang sudah dibangun kepada pengguna apakah prototipe telah sesuai dengan kebutuhan pengguna. Jika sudah sesuai maka langkah 4 akan diambil. Jika tidak sesuai, prototipe direvisi dengan mengulang langkah $1,2$.

4. Pengodean Aplikasi

Pembuatan kode program ialah proses menerjemahkan desain ke dalam bahasa pemrograman. Peneliti menerjemahkan desain prototipe ke dalam kode pemrograman untuk membangun perangkat lunak. Pada tahapan ini digunakan bahasa pemrograman kotlin.

5. Pengujian Aplikasi

Pengujian aplikasi bertujuan untuk menguji setiap elemen perangkat lunak yang dibuat apakah sudah sesuai dengan yang diharapkan. Proses pengujian ini dilakukan secara berkala jika hasil evaluasi belum sesuai maka kembali ke tahap pengodean prototipe sampai produk dinyatakan layak dan lanjut ke tahap produksi akhir.

6. Produksi Akhir

Pada tahap ini, aplikasi yang telah dikembangkan dan diuji, siap digunakan oleh pengguna.

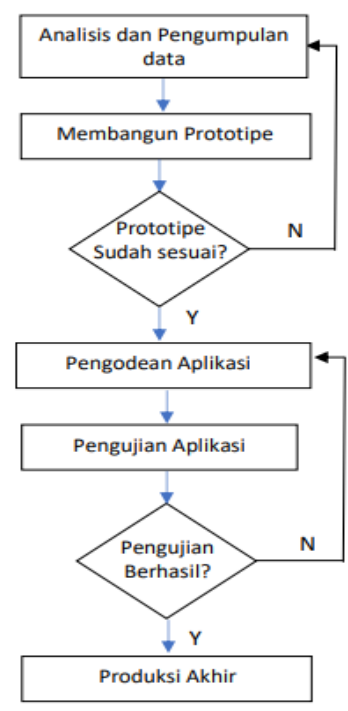

Gambar 1. Prosedur Penelitian

\section{E. Teknik Pengumpulan Data}

\section{Wawancara}

Wawancara adalah teknik pengumpulan data yang dilakukan melalui tatap muka dan tanya jawab langsung antara peneliti dan narasumber atau sember data. Wawancara pada penelitian ini dilakukan untuk memperoleh data yang berkaitan dengan interface dan fitur-fitur aplikasi. Selain itu wawancara juga dilakukan untuk mengumpulkan data tentang analisis kebutuhan dan evaluasi terhadap rancangan software yang dibuat.

\section{Observasi}

Observasi dilakukan dengan maksud mengetahui kondisi sekitar. Observasi dilakukan sebelum dan setelah pembuatan aplikasi. Observasi awal dilaksanakan dengan mengamati kecenderungan pengunjung dan informasi yang tidak terdapat pada replika patung yang ada di Pantai Losari. Setelah aplikasi selesai dibuat selanjutnya observasi ditekankan pada aspek kualitas yang menggunakan aspek functionality suitability, portability, dan efficiency.

3. Kuesioner

Kuesioner adalah teknik pengumpulan data dengan penggunaan angket yang terdiri atas pertanyaan atau pernyataan tertulis kepada responden [6]. Pada penelitian ini, kuesioner digunakan untuk menguji aspek usability yaitu meminta respon kepada pengunjung di Pantai Losari.

F. Instrumen Penelitian

Instrumen penelitian adalah suatu alat yang digunakan untuk mengukur fenomena alam atau sosial yang diamati, secara spesifik fenomena-fenomena ini disebut dengan variabel penelitian. Instrumen digunakan untuk melakukan kuantifikasi (perhitungan atau pengukuran) terhadap suatu objek (variabel).

Dalam penelitian ini, peneliti menggunakan instrumen yang berbeda untuk masing-masing variabel penelitian. Beberapa dari instrumen penelitian dikembangkan oleh peneliti sendiri dan beberapa lainnya merupakan instrumen yang telah valid dan banyak digunakan sebelumnya. Berikut penjelasan untuk masingmasing instrumen penelitian yang digunakan dalam penelitian ini:

1. Instrumen Functional Suitability

Pengujian ini dilakukan dengan menggunakan test case. Test Case adalah sekumpulan instruksi yang dirancang untuk menemukan suatu kesalahan atau cacat dalam sistem perangkat lunak demi mengurangi kegagalan [7]. Tujuan dari 
penggunaan test case adalah untuk memastikan bahwa tidak ada error dalam program. Apabila ditemukan error maka harus segera diperbaiki. Pengujian menggunakan test case ini haruslah didokumentasi.

2. Instrumen Portability

Instrumen yang digunakan untuk pengujian aspek portability adalah tools Test Lab dari Firebase. Aplikasi akan diujicobakan pada berbagai versi android. Pengujian dengan perangkat android dilakukan dengan melakukan instalasi aplikasi pada beberapa perangkat android dengan sistem operasi yang berbeda mulai dari perangkat Android Kitkat hingga Android Pie.

3. Instrumen Usability

Dalam penelitian ini, instrumen untuk mengukur faktor kualitas usability menggunakan USE Questionaire yang dikembangkan oleh STC Usability and User Experience Comunity dari Arnold M. Lund. Dalam penggunaannya, peneliti melakukan beberapa penyesuaian dan penspesifikasian kalimat agar menjadi lebih relevan dengan penelitian. Instrumen ini menggunakan skala likert dengan lima opsi pilihan yaitu: Sangat Setuju (5), Setuju (4), Raguragu (3), Tidak Setuju (2), Sangat Tidak Setuju (1).

4. Instrumen Efficiency

Instrumen pengujian untuk aspek kualitas performance efficiency adalah profiler tools dari IDE Android Studio.

5. Instrumen Kelayakan Materi

Pengujian materi bertujuan untuk memastikan konten yang ditampilkan dengan aplikasi sudah sesuai dengan sumber materi. Instrumen pengujian ini menggunakan kuesioner berupa daftar cek (checklist) tentang patung tokoh pahlawan, kebudayaan dan deskripsinya yang dilakukan dengan cara observasi.

G. Teknik Analisis Data

1. Analisis Functionality Suitability

Pengujian aspek functional suitability menggunakan test case kepada 2 ahli. Test case menggunakan skala pengukuran Gutmann dengan alternatif jawaban sesuai dan tidak sesuai. Hasil pengujian dihitung menggunakan rumus dari matriks Feature Completeness [8]. Matriks yang digunakan untuk mengukur fungsionalitas fitur yang dirancang. Berikut rumus untuk meghitung Feature Completeness:

$$
X=\frac{I}{P}
$$

$\mathrm{I}=$ Jumlah fitur yang dirancang

$\mathrm{P}=$ Jumlah fitur yang berhasil diimplementasikan

Dalam pengujian produk ini dikatakan baik dalam karakteristik functionality jika nilai X mendekati 1 .

2. Analisis Portability

Aplikasi akan diujicobakan pada versi android mulai dari Android Kitkat hingga Android Pie. Masing-masing akan diinstall dan diujikan menggunakan tools Test Lab dari Firebase dan hasilnya didokumentasikan ke dalam Tabel dokumentasi kompatibilitas. Pengujian portability menggunakan angket dengan skala Guttman yang memiliki dua alternatif jawaban sukses untuk 1 dan gagal untuk 0 . Peneliti kemudian mengonversi data yang didapatkan ke dalam bentuk skala persentase untuk mengetahui tingkat kualitas aspek portability aplikasi. Perhitungan persentase kelayakan dilakukan dengan rumus sebagai berikut:

$$
\text { Persentase }=\frac{\text { Skor yang didapatkan }}{\text { Skor maksimal }} \times 100 \%
$$

3. Analisis Usability

Data hasil pengujian usability adalah lembaran kuseioner yang telah terisi dari 20 responden. Kuisioner tersebut menggunakan skala likert dan terdiri dari 30 pertanyaan. Kuisioner yang telah disi oleh responden kemudian dihitung persentase kelayakan, sebagai berikut:

$$
\text { Persentase }=\frac{\text { Skor yang didapatkan }}{\text { Skor maksimal }} \times 100 \%
$$

Hasil yang didapatkan dari persentase kemudian dibandingkan dengan tingkat persentase kelayakan pada Tabel 1.

Tabel 1. Persentase Kelayakan

\begin{tabular}{|c|c|}
\hline Persentase Kelayakan & Kriteria \\
\hline $81 \%-100 \%$ & Sangat Baik \\
\hline $61 \%-80 \%$ & Baik \\
\hline $41 \%-60 \%$ & Cukup \\
\hline $21 \%-40 \%$ & Kurang \\
\hline $0 \%-20 \%$ & Sangat Kurang \\
\hline
\end{tabular}

Sumber: Guritno, 2011

Berdasarkan tabel tersebut aplikasi dikatakan layak apabila hasil persentase yang diperoleh lebih besar $60 \%$.

4. Analisis Efficiency

Analisis aspek kualitas performance efficiency dapat diambil dari penggunaan memori dan CPU. Pengujian dikatakan memenuhi aspek performance efficiency ketika pada penggunaan memori tidak terjadi memori leak dan pada penggunaan CPU tidak menyentuh batas aman yang ditentukan Little Eye yaitu 15\%. Pengujian dilakukan menggunakan android profiler dari IDE Android Studio.

5. Kelayakan Materi

Analisisis aspek kelayakan materi pada media yang dirancang menggunakan analisis deskriptif. Data yang diperoleh dari hasil validasi ahli media adalah data angket yang dikonversikan menjadi skor dengan skala Guttman. Skala Guttman memiliki dua alternatif jawaban. Alternatif jawaban 1 untuk skor tertinggi dan 0 untuk skor terendah. Selanjutnya pengkategorian kualitas materi dilakukan berdasarkan tabel persentase kelayakan materi pada tabel 2 .

$$
\text { Tabel 2. Persentase Kelayakan Materi }
$$

\begin{tabular}{|c|c|}
\hline Skor $(\mathrm{x})$ & Klasifikasi Penilaian \\
\hline $\mathrm{x}>50 \%$ & Valid \\
\hline $\mathrm{x}<50 \%$ & Kurang Valid \\
\hline
\end{tabular}

Sumber: Widyoko, 2014

\section{HASIL DAN PEMBAHASAN}

Setelah menjelaskan rumusan metode yang akan digunakan pada bagian dua, maka pada bagian ketiga dijelaskan hasil penelitian dan pembahasan yaitu:

\section{A. Hasil Penelitian}

Hasil penelitian ini berupa aplikasi pengenalan tokoh pahlawan dan kebudayaan dari replika patung Pantai Losari berbasis android. Pengembangan aplikasi ini bertujuan untuk memudahkan pengunjung memperoleh informasi terkait replika patung tokoh pahlawan dan kebudayaan yang ada di Pantai Losari, aplikasi tersebut dilengkapi dengan fitur pemindaian replika patung melalui kamera smartphone untuk memunculkan informasi. Aplikasi ini dinamakan Losari Statue, dimana kata Losari diambil dari nama lokasi patung yaitu di anjungan Pantai Losari sedangkan statue diambil dari kosa kata bahasa inggris yang 
artinya patung. Berdasarkan model penelitian yang digunakan yakni prototipe, adapun hasil dari prosesnya sebagai berikut:

1. Analisis dan pengumpulan data

Analisis dan pengumpulan data aplikasi dilakukan dengan wawancara dan observasi langsung di anjungan Pantai Losari untuk memperoleh data-data yang dibutuhkan untuk pengembangan aplikasi. Berdasarkan studi lapangan yang telah dilakukan diperoleh data sebagai berikut:

a. Replika patung yang ada hanya menampilkan keterangan nama saja.

b. Tidak terdapat informasi yang mendetail dari replika patung.

c. Pengunjung kesulitan mendapatkan informasi yang jelas terkait replika patung.

d. Sebagian pengunjung belum mengetahui tujuan diperadakannya replika patung.

Selain itu dikumpulkan pula foto dari 23 patung tokoh pahlawan dan kebudayaan sebagai dataset dalam pembuatan model pembelajaran mesin.

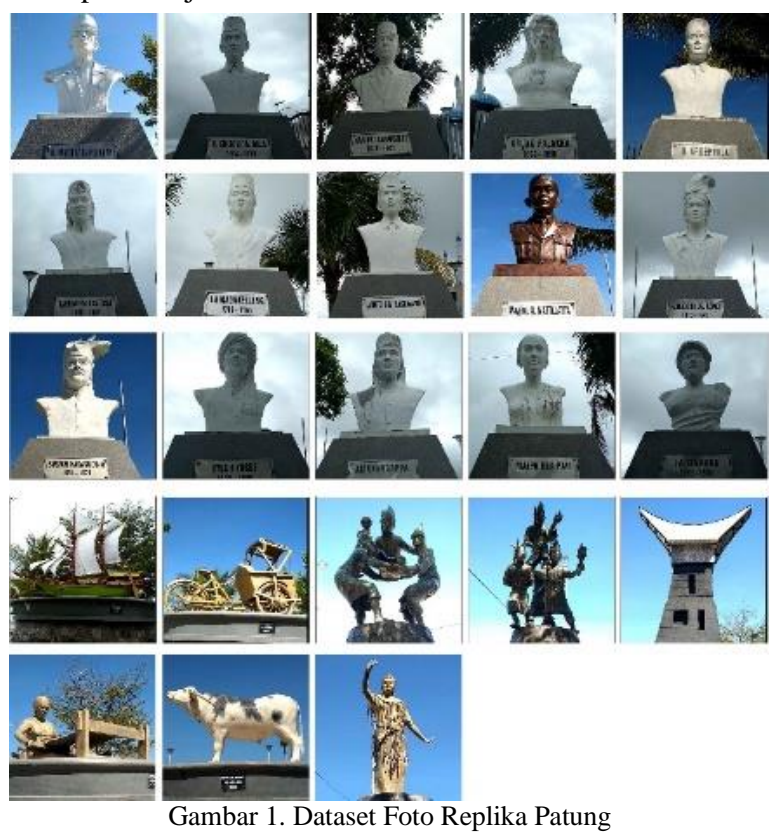

2. Membangun dan mengevaluasi prototipe

Berdasarkan hasil dari analisis dan pengumpulan data awal langkah selanjutnya adalah membangun prototipe yang dilakukan dengan membuat rancangan sementara yang berfokus dengan penyajian pada pengguna. Rancangan ini terdiri rancangan use case diagram, sequence diagram, flowchart, activity diagram, dan user interface. Setelah membangun prototipe, selanjutnya evaluasi dilakukan oleh pengguna, apakah prototipe yang sudah dibangun sudah sesuai dengan keinginan pengguna atau belum. Jika sudah sesuai, maka langkah selanjutnya akan diambil. Namun jika tidak, prototipe akan direvisi.

3. Pengkodean Aplikasi

Pada tahap ini prototipe yang sudah disepakati diterjemahkan ke dalam bahasa pemrograman yang sesuai. Bahasa pemrograman yang digunakan adalah bahasa kotlin dan javascript. Berikut ini ditampilkan hasil pengkodean aplikasi :

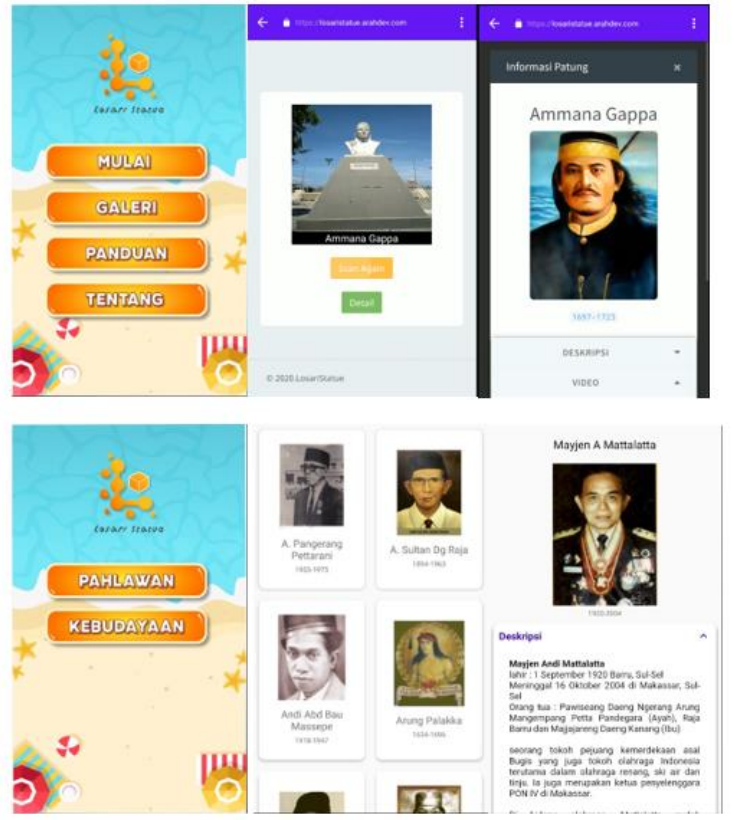

Gambar 2. Hasil Pengkodean aplikasi

4. Pengujian Aplikasi

a. Pengujian ISO/IEC 25010

1) Functionality suitability

Pengujian dilakukan menggunakan test case yang divalidasi oleh 2 validator/ ahli media. Setiap fitur yang berjalan dengan baik maka validator akan memberikan tanda checklist di kolom "valid", namun apabila fungsi tidak berjalan dengan baik maka akan diberi tanda checklist di kolom "invalid" pada instrumen yang diberikan. Berikut rekapitulasi pengujian functionality suitability:

Tabel 3. Rekapitulasi Pengujian Usability

\begin{tabular}{|c|c|c|c|c|c|}
\hline \multirow{2}{*}{ Jawaban } & \multicolumn{2}{|c|}{ Skor Oleh Validator Ahli } & Skor & Total & \multirow{2}{*}{ X } \\
\cline { 2 - 5 } & Validator 1 & Validator 2 & Maks & Skor & \\
\hline Ya & 12 & 12 & 24 & 24 & 1 \\
\hline Tidak & 0 & 0 & 0 & 0 & - \\
\hline
\end{tabular}

Dari pengujian didapatkan nilai $X=1$, sehingga bisa disimpulkan bahwa aplikasi yang telah dikembangkan telah memenuhi aspek functionality suitability dan memiliki kualitas yang baik karena nilai x mendekati nilai 1 .

2) Performance Efficiency

Pada pengujian performance efficiency, aspek yang diamati yaitu penggunaan CPU dan memori. Untuk melakukan pengujian ini menggunakan profiler tools dari IDE Android Studio

a) Memori

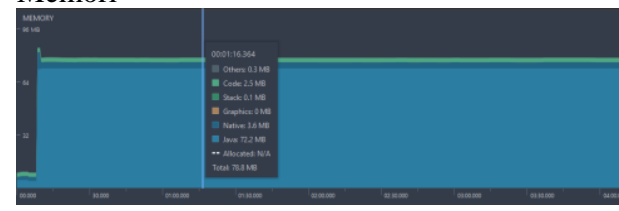

Gambar 3. Penggunaan Memori

penggunaan memori pada waktu dari 0 detik sampai 8 detik mengalami kenaikan yang signifikan. Kenaikan ini diakibatkan karena aplikasi sedang dibuka dan masih melakukan load data. Pada waktu 10 detik keatas penggunaan memori sudah mulai stabil dan 
tidak mengalami perubahan yang signifikan. Penggunaan memori berada pada kisaran 78-84 MB.

b)

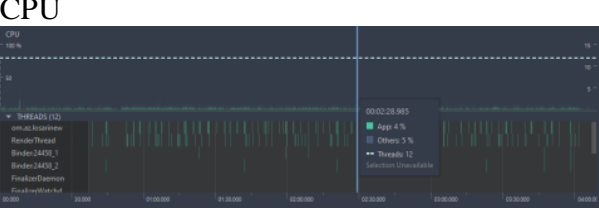

Gambar 4. Penggunaan CPU

Berdasarkan pengujian yang dilakukan, penggunaan cpu berada pada kisaran $1 \%-7 \%$. Penggunaan cpu pada aplikasi per 25 detik dapat dilihat pada tabel 4.

Tabel 4. Penggunaan CPU

\begin{tabular}{|c|c|c|}
\hline No. & Detik ke- & Penggunaan CPU \\
\hline 1 & 25 & $1 \%$ \\
\hline 2 & 50 & $4 \%$ \\
\hline 3 & 75 & $5 \%$ \\
\hline 4 & 100 & $3 \%$ \\
\hline 5 & 125 & $4 \%$ \\
\hline 6 & 150 & $4 \%$ \\
\hline 7 & 175 & $5 \%$ \\
\hline 8 & 200 & $4 \%$ \\
\hline 9 & 225 & $2 \%$ \\
\hline \multicolumn{2}{|c|}{ Total } & $\mathbf{3 2} \%$ \\
\hline \multicolumn{2}{|c|}{ Rerata } & $\mathbf{3} \%$ \\
\hline
\end{tabular}

Berdasarkan tabel diatas penggunaan $\mathrm{CPU}$ memiliki hasil rata-rata sebesar $3 \%$.

Berdasarkan pengujian performance efficiency menggunakan profiler tools dari Android Studio, dilihat dari penggunaan memori dan CPU, maka dapat disimpulkan bahwa pengujian ini dinyatakan sudah memenuhi aspek performance efficiecy, karena pada penggunaan memori tidak menyebabkan memori leak memori leak yang berakibat berhentinya aplikasi (force close) dan pada penggunaan CPU masih dibawah standar yang ditetapkan Little Eye yaitu $15 \%$.

3) Portability

Pengujian portability dilakukan guna memastikan aplikasi dapat digunakan oleh mayoritas perangkat android. Setelah melakukan pengujian didapatkan hasil yang ditunjukkan pada gambar 5 . Hasil pengujian aplikasi yang telah dilakukan oleh Firebase Test Lab sebanyak 10 perangkat berhasil melakukan pengujian. sehingga dapat disimpulkan bahwa aplikasi yang dikembangkan berada pada kategori "Sangat Baik" dan telah memenuhi aspek Portability.

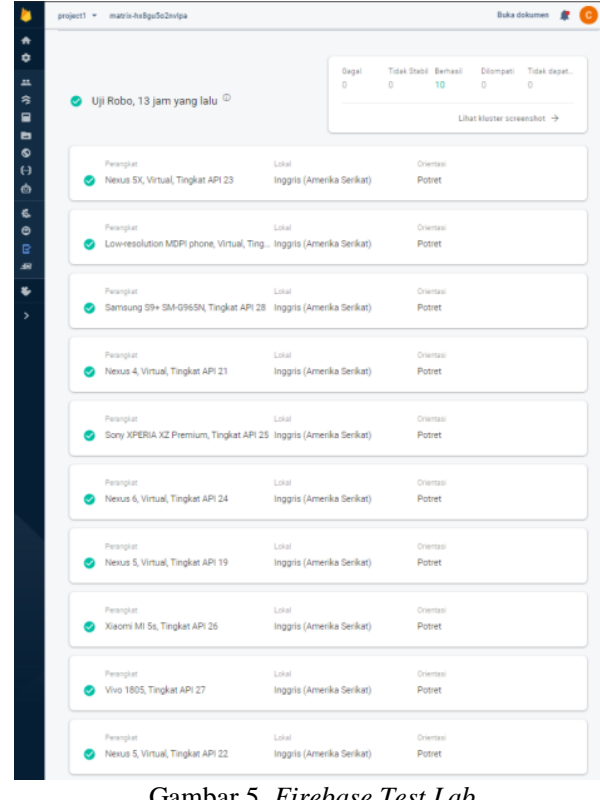

4) Usability

Pengujian usability dilakukan dengan menggunakan kuisioner dari Arnold M. Lund yaitu USE Questionnaire yang terdiri dari 30 pertanyaan dan menggunakan skala Likert 5 (sangat setuju, setuju, ragu-ragu, Tidak setuju, sangat tidak setuju). Angket tersebut memuat beberapa indikator antara lain usefulness (kegunaan), easy of use (mudah digunakan), ease of learning (mudah dipelajari), dan satisfication (kepuasan) Angket diberikan kepada 20 pengunjung Pantai Losari Makassar. Adapun rangkuman hasil pengujian dari 20 responden dapat dilihat pada tabel berikut:

Tabel 5. Rekapitulasi Pengujian Usability

\begin{tabular}{|c|c|c|c|c|c|}
\hline No & $\begin{array}{c}\text { Aspek yang } \\
\text { dinilai }\end{array}$ & $\begin{array}{l}\sum \text { skor 20 } \\
\text { responden }\end{array}$ & $\begin{array}{c}\sum \text { skor } \\
\text { maks }\end{array}$ & $\begin{array}{c}\text { Persentase } \\
(\%)\end{array}$ & Kategori \\
\hline 1 & Usefulnes & 692 & 800 & $86 \%$ & Sangat Baik \\
\hline 2 & Easy of use & 970 & 1100 & $88 \%$ & Sangat Baik \\
\hline 3 & Easy of learning & 366 & 400 & $92 \%$ & Sangat Baik \\
\hline 4 & Satisfication & 612 & 700 & $87 \%$ & Sangat Baik \\
\hline \multicolumn{4}{|c|}{ Rerata Pengujian Usability } & $88 \%$ & Sangat Bail \\
\hline
\end{tabular}

Tabel diatas menunjukkan bahwa persentase skor dari 20 responden pada aspek usefulness sebanyak $86 \%$, aspek easy of use sebanyak $88 \%$, aspek easy of learning sebanyak 92\%, dan satisfication sebanyak $87 \%$. Jika diakumulasikan berdasarkan hasil perhitungan persentase perkategori diperoleh total rerata persentase pengujian usability yaitu $88 \%$. Total rerata persentase pengujian usability apabila dikonversikan ke dalam skala kualitatif sebagaimana pada tabel 1 maka nilai $88 \%$ berada pada interval $81-100 \%$ yaitu mendapat predikat "sangat baik" dan telah memenuhi aspek usability.

b. Pengujian Materi

Pengujian materi dilakukan oleh dua ahli yang kajiannya berkaitan dengan tokoh pahlawan dan kebudayaan. Validasi dilakukan menggunakan angket yanag berkaitan dengan kesesuaian konten tokah pahlawan dan budaya. Hasil pengujian materi bisa dilihat pada tabel dibawah. 
Tabel 6. Rekapitulasi Pengujian Materi

\begin{tabular}{|c|c|c|c|}
\hline \multirow{2}{*}{ Konten } & \multicolumn{2}{|c|}{ Skor yang diperoleh } & Total \\
\cline { 2 - 4 } & Ahli 1 & Ahli 2 & \\
\hline Tokoh Pahlawan & 15 & 15 & 30 \\
\hline Kebudayaan & 8 & 8 & 16 \\
\hline Total & $\mathbf{2 3}$ & $\mathbf{2 3}$ & $\mathbf{4 6}$ \\
\hline
\end{tabular}

Sumber: Hasil Olah Data, 2020

Berdasarkan hasil penilaian uj ahli materi didapatkan persentase $100 \%$. Setalah mendapatkan nilai persentase kelayakan, kemudian dikonversikan kedalam pernyataan sesuai dengan tabel 2 sehingga dapat disimpulkan bahwa aplikasi yang dikembangkan berada pada kategori "Valid".

\section{c. Posisi pengguna}

Aplikasi losari statue memiliki fitur utama memindai objek replika patung tokoh pahlawan dan kebudayaan yang ada di Pantai Losari kemudian mengklasifikasikan objek tersebut untuk ditampilkan informasinya. Dalam proses klasifikasi, aplikasi membandingkan data input dari kamera smartphone dengan model pembelajaran mesin yang telah dilatih sebelumnya. Oleh karena itu tingkat keakuratan hasil klasifikasi objek patung sangat dipengaruhi oleh data inputnya. Agar data input dapat diperoleh secara maksimal maka perlu diperhatikan jarak dan posisi sudut pengguna terhadap objek replika patung.

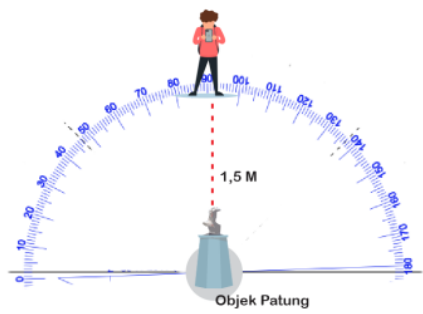

Gambar 6. Jarak dan Posisi Sudut Pengguna Untuk posisi sudut pengguna terhadap objek patung diperoleh hasil observasi pada tabel 7 .

Tabel 7. Hasil Observasi Posisi Sudut Pengguna

\begin{tabular}{|c|c|c|c|c|c|c|c|c|c|c|c|}
\hline \multirow{2}{*}{ No. } & \multirow{2}{*}{$\begin{array}{l}\text { Replika } \\
\text { patung }\end{array}$} & \multicolumn{10}{|c|}{$\begin{array}{c}\text { sudut } \\
\end{array}$} \\
\hline & & $0^{\circ}$ & $20^{\circ}$ & $40^{\circ}$ & $60^{\circ}$ & $80^{\circ}$ & $100^{\circ}$ & $120^{\circ}$ & $140^{\circ}$ & $160^{\circ}$ & $180^{\circ}$ \\
\hline 1 & $\begin{array}{l}\text { A. Pangerang } \\
\text { Pettarani }\end{array}$ & - & - & - & - & v & $\sqrt{ }$ & - & - & - & - \\
\hline 2 & $\begin{array}{l}\text { A. Sultan Dg } \\
\text { Raja }\end{array}$ & - & - & - & - & $\checkmark$ & $\checkmark$ & - & - & - & - \\
\hline 3 & $\begin{array}{l}\text { Andi Abd } \\
\text { Bau Massepe }\end{array}$ & - & - & - & - & $\checkmark$ & $\checkmark$ & - & - & - & - \\
\hline 4 & \begin{tabular}{l|} 
Arung \\
Palakka \\
\end{tabular} & - & - & - & $\checkmark$ & $\checkmark$ & $\sqrt{ }$ & $\sqrt{ }$ & - & - & - \\
\hline 5 & H. Aroeppala & - & - & - & - & $\sqrt{ }$ & $\sqrt{ }$ & - & - & - & - \\
\hline 6 & $\begin{array}{l}\text { Karaeng } \\
\text { Patingalloang }\end{array}$ & - & - & - & - & $\checkmark$ & $\checkmark$ & - & - & - & - \\
\hline 7 & $\begin{array}{l}\text { La } \\
\text { Madukelleng }\end{array}$ & - & - & - & - & v & $\checkmark$ & - & - & - & - \\
\hline 8 & \begin{tabular}{l|} 
Lanto Dg \\
Pasewang \\
\end{tabular} & - & - & - & - & $\checkmark$ & $\sqrt{ }$ & - & - & - & - \\
\hline 9 & $\begin{array}{l}\text { Mayjen A } \\
\text { Mattalatta }\end{array}$ & - & - & - & $\checkmark$ & $\checkmark$ & $\checkmark$ & $\sqrt{ }$ & - & - & - \\
\hline 10 & $\begin{array}{l}\text { Ranggong } \\
\text { Dg Romo }\end{array}$ & - & - & - & $\checkmark$ & v & $\checkmark$ & $\checkmark$ & - & - & - \\
\hline 11 & $\begin{array}{l}\text { Sultan } \\
\text { Hasanuddin }\end{array}$ & - & - & - & $\sqrt{ }$ & $\checkmark$ & $\checkmark$ & $\checkmark$ & - & - & - \\
\hline 12 & Syech Yusuf & - & - & - & - & $\mathrm{v}$ & $\sqrt{ }$ & - & - & - & - \\
\hline 13 & $\begin{array}{l}\text { Ammana } \\
\text { Gappa }\end{array}$ & - & - & - & - & v & $\checkmark$ & - & - & - & - \\
\hline 14 & $\begin{array}{l}\text { Maipa } \\
\text { Deapati }\end{array}$ & - & - & - & $\sqrt{ }$ & $\checkmark$ & $\checkmark$ & $\checkmark$ & - & - & - \\
\hline 15 & La sinrang & & & - & $\sqrt{ }$ & $\sqrt{ }$ & $\sqrt{ }$ & $\sqrt{ }$ & - & - & \\
\hline
\end{tabular}

Observasi dilakukan terhadap 15 replika patung tokoh pahlawan yang memiliki bentuk setengah badan dan detail patung yang membedakan dengan replika patung lainnya hanya terletak di bagian depan patung. Sedangkan untuk objek patung kebudayaan tidak dilakukan observasi karena bentuk replika patung tampak secara detail dari segala sisi patung sehingga pengguna dapat melakukan scan dari berbagai sudut.

Berdasarkan tabel 7 sudut efektif dalam memindai objek patung tokoh pahlawan yaitu berada pada interval $60^{\circ}-120^{\circ}$ dengan ketentuan sudut yang digunakan yaitu sudut $0^{\circ}$ berada pada sisi kiri patung, sudut $180^{\circ}$ berada sisi kanan patung, sudut $270^{\circ}$ berada sisi belakang patung, sudut $90^{\circ}$ berada pada sisi depan patung. Berdasarkan hasil observasi terhadap penggunaan aplikasi losari statue diperoleh bahwa jarak maksimal pengguna yakni 1,5 meter dari objek patung selain itu posisi sudut yang baik berada pada interval $60^{\circ}-120^{\circ}$ untuk replika patung tokoh pahlawan.

\section{B. Pembahasan}

Hasil pengembangan dalam penelitian ini berupa media informasi pada platform android yang diberi nama "Losari Statue". Aplikasi losari statue ini memberikan informasi kepada masyarakat khususnya pengunjung di Pantai Losari terkait replika patung tokoh pahlawan dan kebudayaan yang ada di Pantai Losari. Aplikasi ini dikembangkan dengan memanfaatkan teknologi machine learning kit yaitu teachable machine untuk membuat model pembelajaran mesin yang selanjutnya dapat digunakan untuk mengenali replika patung tokoh pahlawan dan kebudayaan yang ada di Pantai Losari. Aplikasi ini memiliki komponen utama, yaitu: a) halaman menu utama, b) menu galeri tokoh pahlawan dan kebudayaan, c) menu panduan, d) menu tentang.

Aplikasi losari statue menyajikan informasi kepada pengguna melalui dua menu yaitu menu mulai dan menu galeri. Pada menu mulai, pengguna terlebih dahulu mencari objek patung tokoh pahlawan dan kebudayaan di Pantai Losari kemudian memindai patung tersebut dengan memosisikan kamera smartphone ke arah replika patung hingga replika patung terdeteksi dan dapat menampilkan detail informasinya. Untuk memaksimalkan pemindaian objek patung, pengguna harus berjarak maksimal 1,5 meter dari replika patung selain itu posisi pengguna pada saat memindai replika patung khususnya patung tokoh pahlawan yaitu berada tepat di depan objek patung atau pada sudut $90^{\circ}$ dan pengguna dapat bergeser pada interval sudut antara $60^{\circ}-120^{\circ}$ dengan objek patung sebagai titik sudutnya $\left(0^{\circ}\right.$ berada kiri patung dan $180^{\circ}$ pada sisi kanan patung) sedangkan untuk memindai replika patung kebudayaan dapat dilakukan dari berbagai sisi. Selanjutnya informasi juga dapat diperoleh tanpa memindai patung yaitu pada menu galeri yang menampilkan daftar tokoh pahlawan dan kebudayaan dimana pengguna dapat langsung memilih tokoh pahlawan ataupun kebudayaan yang akan dilihat detail informasinya.

Aplikasi ini dirancang menggunakan model prototipe. Tahapan-tahapan perancangan model prototipe yaitu analisis dan pengumpulan data, membangun prototipe, pengkodean aplikasi, pengujian aplikasi dan produksi akhir. Proses perancangan diawali dengan menganalisis kebutuhan dengan melakukan wawancara dan observasi langsung di anjungan Pantai Losari. Kemudian dilakukan perancangan use case diagram, sequence diagram, flowchart, activity diagram yang menggambarkan aplikasi yang akan dibangun, kemudian dari rancangan tersebut disusunlah tampilan aplikasi.

Pengujian aplikasi ini dilakukan dengan beberapa tahapan, adapun tahapannya yakni, validasi ahli (expert) dan tanggapan pengguna (user). Berdasarkan kedua tahapan pengujian tersebut, diperoleh hasil bahwa aplikasi Losari Statue layak untuk diimplementasikan. Hal ini terlihat dari hasil pengujian yang dilakukan dimana semua kriteria evaluasi hasil pengujian berhasil. Oleh karena itu, aplikasi ini dapat dikatakan berjalan dengan baik 
sesuai dengan rancangan sebelumnya. Validasi expert yaitu meminta tanggapan dan saran dalam pengujian yang dilakukan oleh dua orang ahli sistem dan dua orang ahli materi yang bertugas memberi penilai terhadap aplikasi dan materi aplikasi yang telah dibuat dan menunjukkan hasil yang baik dan layak untuk diimplementasikan. Selain itu, responden atau pengguna memberikan tanggapan aplikasi yang telah dibuat menunjukkan hasil yang baik dan layak untuk diimplementasikan.

Pengujian aplikasi ini dilakukan dengan menggunakan standar ISO/IEC 25010 sebagai acuan pengujian. Faktor kualitas menurut ISO 25010 meliputi 8 karakteristik, dimana pada penelitian ini digunakan empat aspek yaitu:

1. Functional Suitability merupakan merupakan faktor kualitas yang menunjukkan program telah mampu menjalankan fungsi sesuai dengan rancangan yang telah dikembangkan.

2. Performance efficiency merupakan tingkat kinerja relatif terhadap sumber daya yang digunakan dalam kondisi yang ditetapkan.

3. Portability merupakan kemampuan program untuk beradaptasi dengan lingkungan yang berbeda.

4. Usability merupakan sejauh mana sebuah produk atau sistem dapat digunakan oleh pengguna tertentu untuk mencapai tujuan dengan efektif, efisien, dan kepuasan tertentu dalam konteks pengguna.

Berdasarkan hasil pengujian yang telah dilakukan, aspek functionality suitability bernilai 1 , artinya aplikasi memiliki kualitas yang baik serta kemampuan untuk menyediakan fungsi sesuai kebutuhan pengguna saat digunakan dalam kondisi tertentu. Aspek portability dilakukan dengan penginstalan aplikasi di 10 perangkat smartphone dengan spesifikasi dan versi sistem operasi Android yang berbeda lalu dijalankan dimana aplikasi terpasang dan berjalan dengan baik, artinya aplikasi memiliki kemampuan untuk ditransfer dari satu lingkungan ke lingkungan lain. Aspek performance efficiency dilakukan menggunakan profiler tools dari IDE Android Studio dengan melihat penggunaan memori dan CPU dari aplikasi dimana penggunaan memori tidak menyebabkan memori leak dan penggunaan CPU masih dibawah standar yang ditetapkan Little Eye yaitu 15\%, artinya aplikasi telah memenuhi aspek performance efficiency. Pengujian terakhir yaitu aspek usability dilakukan dengan pembagian angket terhadap 20 responden, berdasarkan hasil perhitungan diperoleh persentase nilai rata-rata $88 \%$ dan berada pada kategori sangat baik, artinya aplikasi memiliki kemampuan untuk dipahami, dipelajari, digunakan dan menarik bagi pengguna.

Berdasarkan hasil pengujian yang telah dilakukan maka dapat disimpulkan bahwa keseluruhan aspek yang diuji telah memenuhi standar kualitas perangkat lunak. Hasil pengujian ini juga merepresentasikan jaminan kualitas produk yang dikembangkan sehingga dinyatakan dapat diimplementasikan pada sistem yang sesungguhnya.

\section{PENUTUP}

A. Kesimpulan

Berdasarkan hasil penelitian yang dilakukan, didapatkan saran sebagai berikut:

1. Hasil pengembangan dalam penelitian ini berupa media informasi pada platform android diberi nama "Losari Statue". Aplikasi losari statue ini memberikan informasi kepada masyarakat khususnya pengunjung di Pantai Losari terkait replika patung tokoh pahlawan dan kebudayaan yang ada di Pantai Losari. Aplikasi ini memiliki komponen utama, yaitu: a) halaman menu utama, b) menu galeri tokoh pahlawan dan kebudayaan, c) menu panduan, d) menu tentang. Tahapan penyajian informasi dalam aplikasi ini dengan memindai replika patung di Pantai losari kemudian akan menampilkan informasi dari objek yang terdeteksi. Selain itu informasi juga dapat dilihat secara langsung pada menu galeri.

2. Aplikasi losari Statue dinilai layak karena hasil pengujian menunjukkan bahwa aplikasi ini telah memenuhi standar ISO/IEC 25010 dalam 4 aspek pengujian. Adapun hasil pengujian aspek functionality mendapatkan nilai 1 dengan kualitas baik. Pengujian aspek usability dengan jumlah responden sebanyak 20 orang memperoleh rata-rata persentase kelayakan sebesar $88 \%$ dengan kategori sangat baik. Pada aspek performance efficiency telah terpenuhi dengan rata-rata penggunaan CPU berada pada batas aman penggunaan berdasarkan ketentuan little eye dan penggunaan aplikasi juga tidak menyebabkan memory leak dan force close. Pengujian aspek portability, persentase kesuksesan dengan 10 perangkat android adalah $100 \%$.

B. Saran

Berdasarkan hasil penelitian, adapun saran yang diberikan peneliti sebagai berikut:

1. Bagi pemerintah khususnya pemerintah kota makassar diharapkan dapat mensosialisasikan penggunaan aplikasi ini sehingga dapat memberikan manfaat yang lebih luas bagi masyarakat khususnya pengunjung Pantai Losari.

2. Bagi peneliti atau pengembang, diharapkan dapat melakukan penelitian lanjutan terkait perbandingan kemampuan aplikasi dan kemampuan manusia dalam mengenali objek patung, pengembangan algoritma yang mampu meningkatkan akurasi dalam mengenali objek pada sudut tertentu, penambahan fitur dari aplikasi berupa lokasi objek patung dengan google maps, serta pengembangan aplikasi pada platform selain android.

\section{DAFTAR PUSTAKA}

[1] Setiawan, Iwan, Justinus Andjarwirawan, dan Andreas Handojo. 2013. Aplikasi Makassar Tourism pada Kota Makassar Berbasis Android. Skripsi Universitas Kristen Petra Surabaya.

[2] Jannah, Miftahul. 2015. Pantai Losari. http://beritamks.com/pantai-losari/. Diakses 20 September 2019.

[3] Kharismawati, Rina. 2015. Anjungan Pantai Losari: Pesona dan Dilema Ruang Publik Kota Makassar. kompasiana.com/missrinna/anjungan-pantai-losari-pesonadan-dilema-ruang-publik-kota-makassar. Diakses 20 September 2019.

[4] Tempo.co. 2012. Miniatur Budaya Makassar di Anjungan. Tempo.com.https://travel.tempo.co/read/449643/miniaturbudaya-makassar-di-anjungan/full\&view=ok. Diakses pada tanggal 20 September 2019.

[5] Pressman, Roger S. 2012. Rekayasa Perangkat Lunak, jilid I. Yogyakarta: Andi.

[6] Sugiono. 2012. Metode Penelitian Kuantitatif Kualitatif dan R\&D. Bandung:Alfabeta.

[7] Agarwal, B.B., S. P. Tayal, M. Gupta. 2010. Software Engineering and Testing. 20 September 2019. Books.google.co.id/.

[8] Acharya, A., \& Sinha, D. 2013. Assessing the Quality of MLearning Systems using ISO/IEC 25010. International Journal of Advanced Computer Research, 67-75. 